\title{
Penggunaan Big Data dalam Perancangan Arsitektur Penjara
}

\author{
Muhammad Fikri Rajal Izza dan Murni Rachmawati \\ Departemen Arsitektur, Fakultas Arsitektur Desain dan Perencanaan, Institut Teknologi Sepuluh Nopember (ITS) \\ e-mail: murnirarch@arch.its.ac.id
}

\begin{abstract}
Abstrak-Satu dekade terakhir berbagai bidang seperti ekonomi, kedokteran, periklanan, media massa dan seterusnya mulai menggunakan big data atau dalam bahasa Indonesia maha data dalam menentukan berbagai keputusan. Penggunaannya begitu luas dan dari lingkup paling formal seperti pekerjaan hingga lingkup yang paling privat seperti bagaimana kita mengatur hubungan percintaan kita. Penelitian ini bertujuan untuk mencari adakah posibilitas pemanfaatan big data dalam merancang sebuah desain arsitektur. Dalam mencari konteks yang optimal bagi penggunaan big data dalam merancang sebuah desain arsitektur pada penelitian ini perancang menggunakan Complex Controlled Data sebagai proposisi yang membawa perancang pada tipologi penjara tepatnya di Rutan Klas 1 Surabaya. Lewat proposisi yang sama pula perancang melakukan analisa pendekatan perilaku pada konteks yang ditentukan dengan metode statistik data yang kemudian membawa perancang pada sebuah masalah lokal yaitu minimnya posibilitas interaksi antara narapida atau tahanan yang membuat kian hari identitasnya tergerus. Hal tersebut kontradiktif mengigat bahwa sistem peradilan di Indonesia menamai penjara dengan sebutan Lembaga Pemasyarakatan. Pada riset ini objek penjara hanya merupakan tipologi atau objek uji dari isu yang perancang angkat yaitu tentang penggunaan metode pengolahan big data dalam perancangan sebuah arsitektur. Titik berat perancangan ini terletak pada proses perancangan arsitekturnya, tentang pengumpulan, pengolahan, dan pengambilan keputusan rancang berbasis data. Melihat hasil akhir rancang (dalam riset ini data mengantarkan perancang untuk menjadikan tipologi penjara sebagai objek rancang yang dianggap dapat mendapatkan dampak paling optimum dengan analisa big data) Penjara Medaeng Rutan Klas 1 Surabaya yang didasarkan oleh kompleksitas dan prefensi hidup manusia berhasil ditransformasikan menjadi aspek formal dari bangunan rancang dan hal membuktikan bahwa Big Data dapat juga diterapkan dalam mendesain sebuah perancangan arsitektur dan menjadi salah satu alternatif metode dalam merancang suatu arsitektur.
\end{abstract}

Kata Kunci-Big Data, Complext Controled Data, Data, Identitas, Interaksi, Penjara, Rutan Klas 1 Surabaya.

\section{PENDAHULUAN}

$\mathrm{B}$ IG Data merupakan sebuah kumpulan data yang tersebar luas dalam kuantitas yang banyak dan cepat [1]. Big data belakangan digunakan dalam beberapa perusahaan untuk menentukan sebuah keputusan, seperti layanan transportasi online, produk komersil dan lain sebagainya. Big data diklaim dapat memberikan pertimbangan yang lebih kemperhensif karena dapat memberikan informasi yang variatif dalam jumlah yang banyak untuk berikutnya diolah. Pertanyaan yang kemudian timbul adalah, adakah posibilitas penggunaan big data dalam merancang sebuah arsitektur? Adakah kemungkinan untuk mengolah sebuah data yang begitu kompleks untuk menentukan keputusan sebuah rancangan arsitektur.

Untuk mendapatkan konteks uji yang tepat untuk merancang menggunakan big data perancang mencoba membuat iterasi konteks yang terbagi diklasifikasikan menjadi beberapa poin, yaitu: tempat, waktu, aktivitas, tipologi, dan lokasi tapak

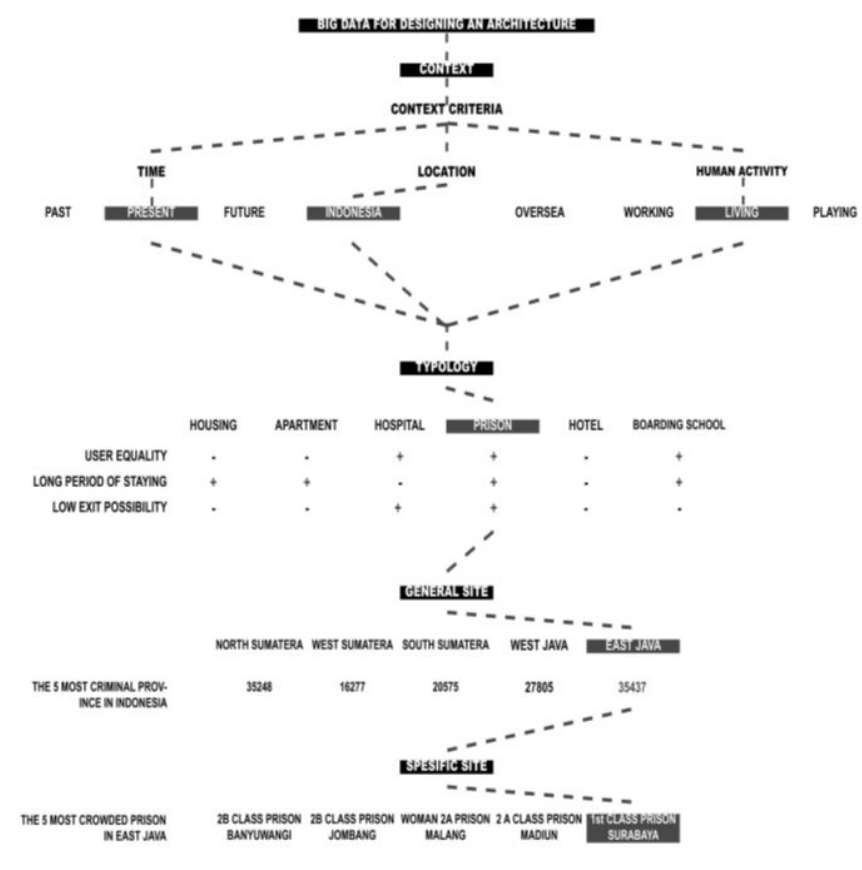

Gambar 1. Diagram Penentuan Konteks Objek Rancang

Diagram diatas menjelaskan bagaimana perancang menentukan konteks hingga ke poin yang paling spesifik yaitu lokasi site dengan membuat parameter, posibilitas, dan membuat keputusan hingga Rutan Klas 1 Medaeng dipilih sebagai site objek rancang dan Penjara dipilih sebagai tipologi rancang.

\section{II.METODA PERANCANGAN}

Pendekatan perilaku manusia dengan proposisi data kompleks yang terkontrol membawa kita pada sebuah koridor kerja untuk melihat segala aspek dalam karya ini dalam bentuk data. Seperti yang di ditulis MVRDV dalam buku Metacity 
Datatown yang mereka manifestasikan dalam Datatown dimana sebuah kota dan seisinya termasuk arsitektur didalamnya, semua didefinisikan berdasarkan data, tidak ada topologi, ideologi, representasi, dan bahkan konteks, hanya data dalam jumlah yang besar [2]. Dalam merancang saya membagi dalam beberapa tahapan.

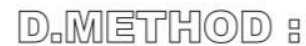 GENERAL, SPESIFIC,}

GENERAL
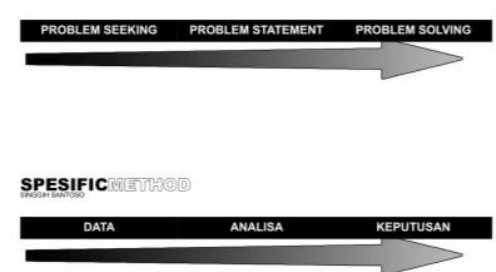

Gambar 2. Diagram Metode Perancangan.

Pena menekankan bahwa terdapat perbedaan antara problem seeking method dan problem solving method di dalam arsitektur [3]. Keduanya memiliki karakter metode yang berbeda. Problem Solving method lebih menekankan pada creative effort. metodanya selalu memiliki benang merah. Selalu diawali dengan defining the problem / problem statement. Sedangkan problem seeking adalah proses yang dilakukan hingga dapat mendefinisikan problem. Dalam posisi ini problem statement merupakan penghubung antara problem seeking dan problem solving.

Secara umum Singgih Santoso dalam buku Statistik Parametrik tentang prinsip ilmu statistik, yaitu : mengumpulkan data, meringkas/menyajikan data, menganalisis dengan metode tertentu, menginterpretasi hasil analisis tersebut [4]. Diagram diatas menunjukkan bahwa setelah sebuah masalah yang terdefinisi pada tahapan sebelumnya dan mengarahkan pada penyelesaian masalah, tahap ini adalah tahap dimana masalah tersebut diperkaya dengan data untuk kemudian dianalisa dan mencari kriteria untuk diolah selanjutnya.

Setelah mendapatkan beberapa kriteria, tahap ini adalah dengan menyusun kriteria tersebut dan mengembangkan sebanyak mungkin posibilitas keputusan untuk kemudian diterjemahkan secara bentuk. Hal itu dijabarkan dalam diagram [5]. Saat solusi sudah diputuskan, tahap selanjutnya yaitu mengembalikan lagi proses metode ke tahap pertama untuk menyelesaikan hal yang lebih spesifik.

\section{HASIL EKSPLORASI}

Berdasarkan masalah yang diutarakan, aktivitas serta luasan program dan kriteria serta requirement yang ada, desain harus mampu menjadi solusi terkait densitas rutan, kurangnya identitas penghuninya, adanya keamanan dan pengawasan bersama antar tiap pihak, dan membantu lingkungan sekitar. Berdasarkan analisa pihak dan pendekatan perilaku serta preferensi, diambil sebuah konsep yaitu Konsep Ekosistem Interaksi.
Ekosistem interaksi adalah konsep yang memungkinkan membuat sebuah lingkungan binaan dimana segala pihaknya disetarakan, dikuatkan, dan dikaitkan. Ekosistem interaksi adalah konsep dimana dalam mencapai sebuah tujuan, kesepakatan, atau batasan teritorial, penggunaan partisi diminimalisir justru dikuatkan dengan memberi titik - titik interaksi. Ekosistem Interaksi memposisikan hubungan antar individu (dalam hal ini 3 pihak utama, dan sub pihak didalamnya) sebagai sebuah ekosistem, bahwa tidak ada yang lebih tinggi, lebih rendah, semuanya saling berkaitan dan saling memiliki ketergantungan.

Dalam mendapatkan hasil rancang yang optimum, perancang membagi proses eksplorasi dan pematangan konsep menjadi 2 bagian konsep yaitu: Konsep Umum dan Konsep Spesifik.

\section{A. Konsep Umит}

1. Konsep Zonasi

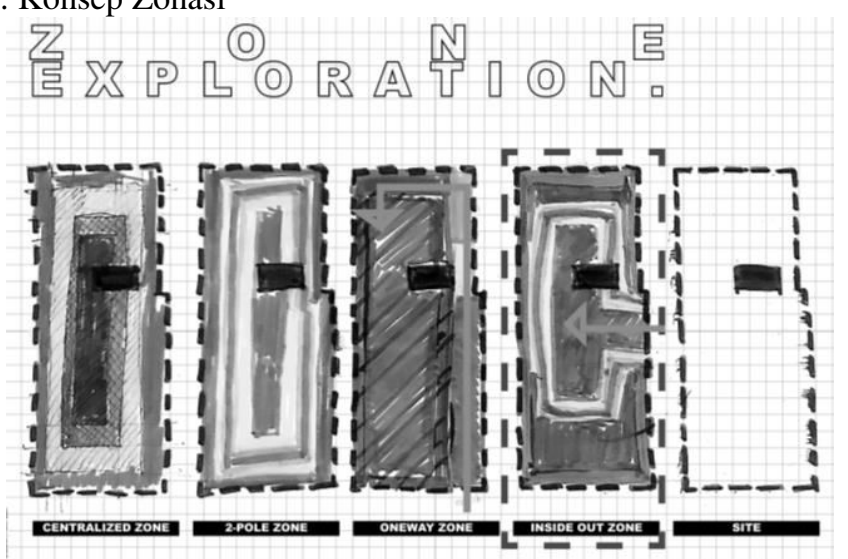

Gambar 3. Ilustrasi Eksplorasi Zoning

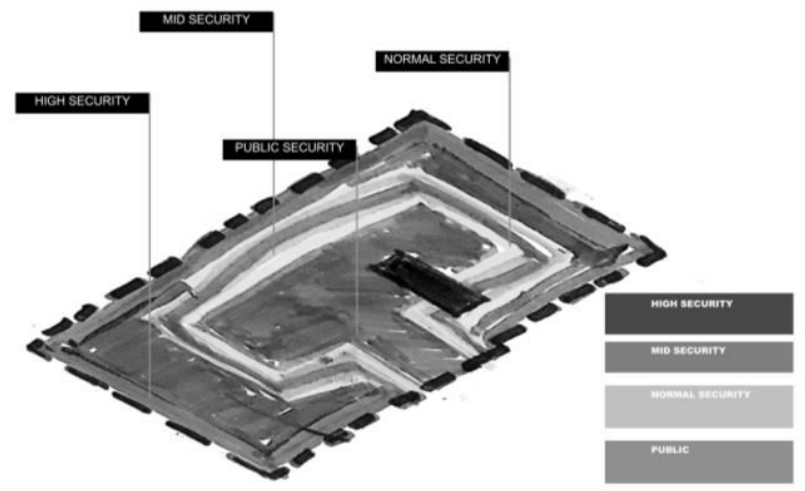

Gambar 4. Ilustrasi Inside-Out Zone

Gambar diatas menunjukan eksplorasi zonasi dengan membuat diagram sketsa diatas outline tapak. Empat opsi yang didapat (Centralized Zone, 2-Pole Zone, Oneway Zone, Inside Out Zone) kemudian diuji kembali dengan kriteria dan konsep zonasi yang sebelumnya ditulis untuk kemudian dipilih satu opsi zonasi yang dianggap paling memiliki kecocokan dengan konsep yang ditentukan. Opsi Inside-Out Zone dipilih sebagai opsi yang dianggap optimum dimana zonasi tersebut memberikan pengalaman ruang public (hijau) untuk bias langsung masuk di area inti (tengah) dari site tersebut sehingga bias langsung menyaksikan bagaimana kondisi keseharian penjara dan disaat yang bersamaan membuat sipir terawasi 
selagi mereka mengurus narapidana di penjara. Namun begitu untuk dapat benar - benar melakukan kontak fisik dengan narapidana orang publik dibatasi oleh beberapa lapis keamanan sehingga penjara dapat tetap aman dan terawasi antara mereka yang dating dan pergi.

2. Konsep Sekuens
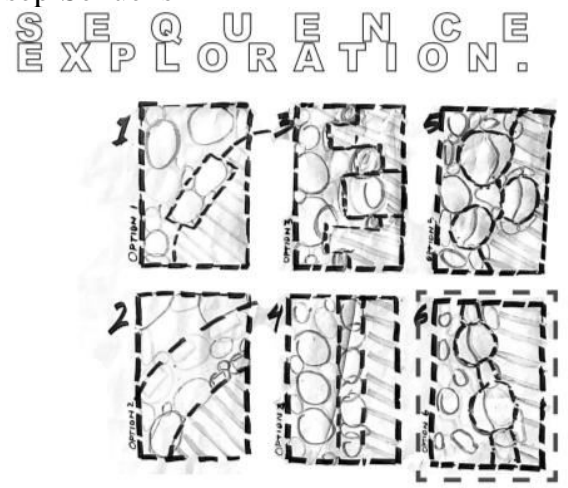

Gambar 5. Ilustrasi Eksplorasi sekuens.

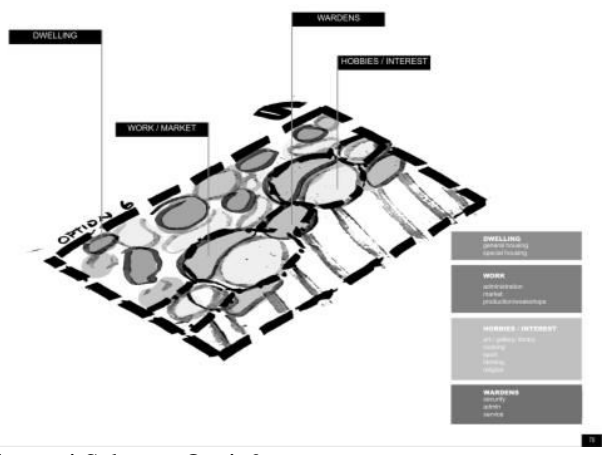

Gambar 6. Ilustrasi Sekuens Opsi-6.

Gambar 6 menunjukan eksplorasi sekuens dengan membuat diagram sketsa diatas outline tapak. Enam opsi yang didapat (Opsi 1, 2, 3 , 5, 6) kemudian diuji kembali dengan kriteria dan konsep sekuens yang sebelumnya ditulis untuk kemudian dipilih satu opsi sekuens yang dianggap paling memiliki kecocokan dengan konsep yang ditentukan. Opsi ke-6 dipilih sebagai opsi yang dianggap optimum dimana zonasi tersebut memberikan kemungkinan pendatang atau orang disekitar lingkungan untuk beraktivitas bersama/berdekatan dengan narapidana tentunya dengan pengawasan sipir. Penataan sedemikian rupa juga memberikan kemungkinan interaksi yang lebih terbuka dalam pengawasan

3. Konsep Bentuk

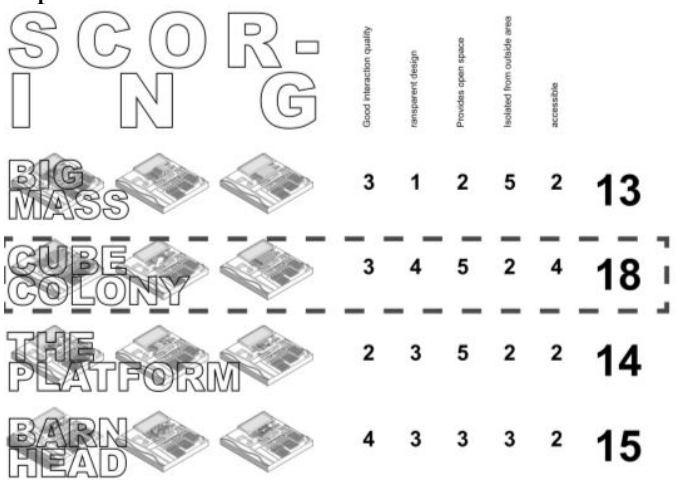

Gambar 7. Ekplorasi Bentuk dan Penilaian Bentuk.
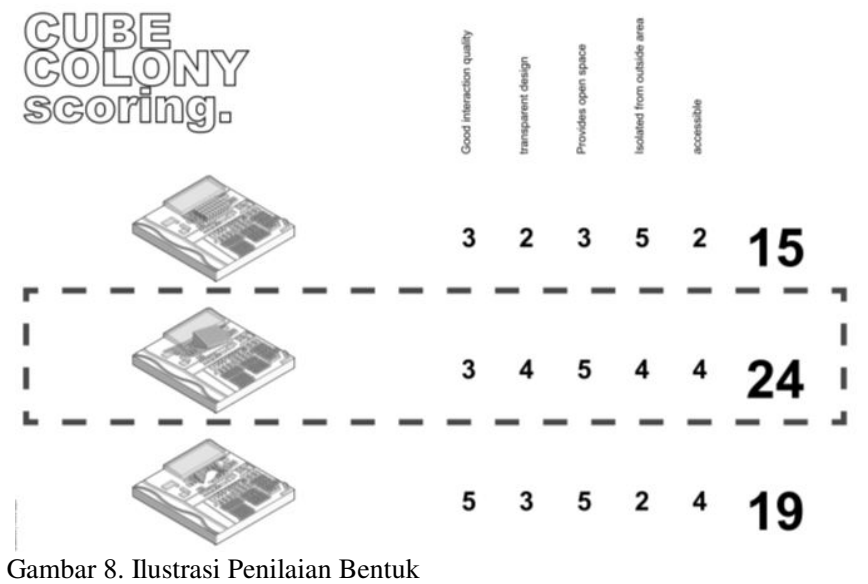

Gambar 8 menunjukan eksplorasi bentuk dengan membuat ekplorasi model $3 \mathrm{~d}$ digital dan maket studi berdasarkan parameter kriteria yang ditentukan. 12 model yang dieksplorasi dikelompokan berdasarkan kedekatan bentuk secara 


\section{4.. Layer-Mix}

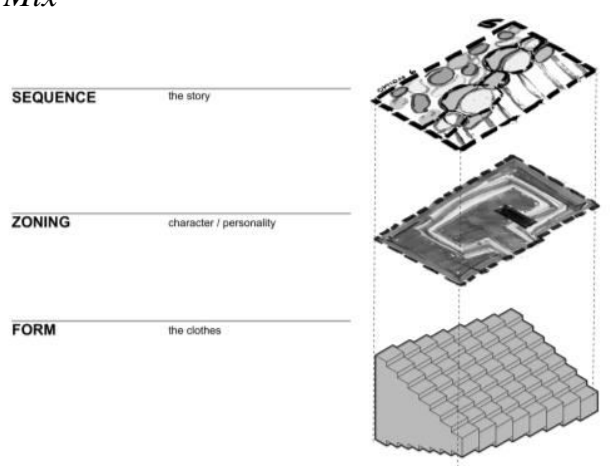

Gambar 9. Ilustrasi Layer Mix.

Setelah semua opsi pembagian konsep terpilih, perancang menyatukan dan menvisualisasikan konsep umum tersebut dalam diagram perancangan penjara.

\section{B. Konsep Spesifik}

Konsep spesifik merupakan penunjang konsep umum dimana bagian - bagian konsep umum (zoning, sekuens, bentuk, dan situasi) yang sudah digabung dipecah kembali menjadi beberapa bagian yaitu : bentuk, program, dan scenario untuk kemudian di ekplorasi lebih spesifik untuk kemudian diterjemahkan dalam bangunan.

1. Konsep Bentuk Spesifik MODELLXXIPLRATUON
anal]YSLIS
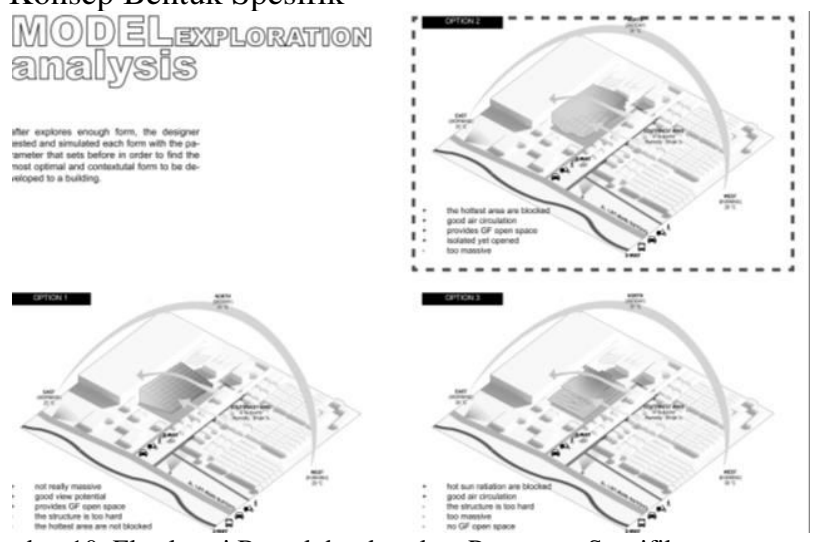

Gambar 10. Eksplorasi Bentuk berdasarkan Parameter Spesifik.

Setelah parameter spesifik bentuk ditentukan, perancang mengeksplorasi lagi bentuk akhir (opsi ke-2 cube colony) menjadi 3 jenis untuk kemudian diuji dan dinilai secara kualitatif berdasarkan parameter spesifik. Berdasarkan hasil uji, opsi-2 eksplorasi bentuk spesifik dianggap paling optimal.

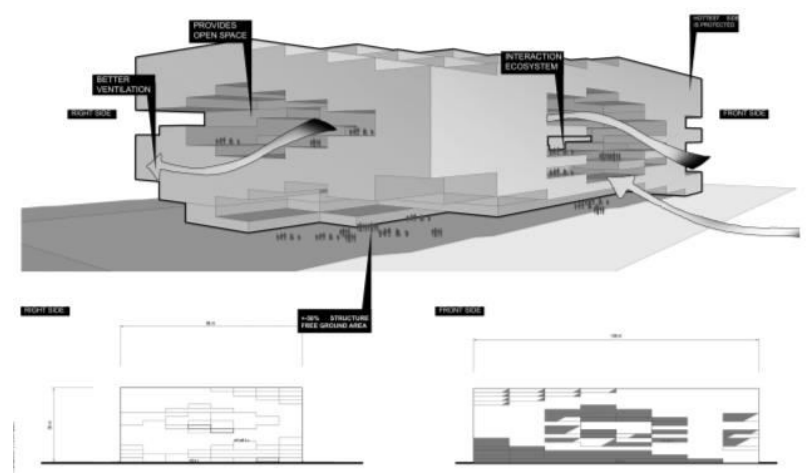

Gambar 11. Opsi Bentuk ke-2.
Berdasarkan Gambar 11 opsi ke-2 bentuk spesifik dapat memberikan ruang tebuka, interaksi, penyinaraan dan sirkulasi penghawaan yang baik untuk bangunan penjara yang di kriteriakan

2. Konsep Program
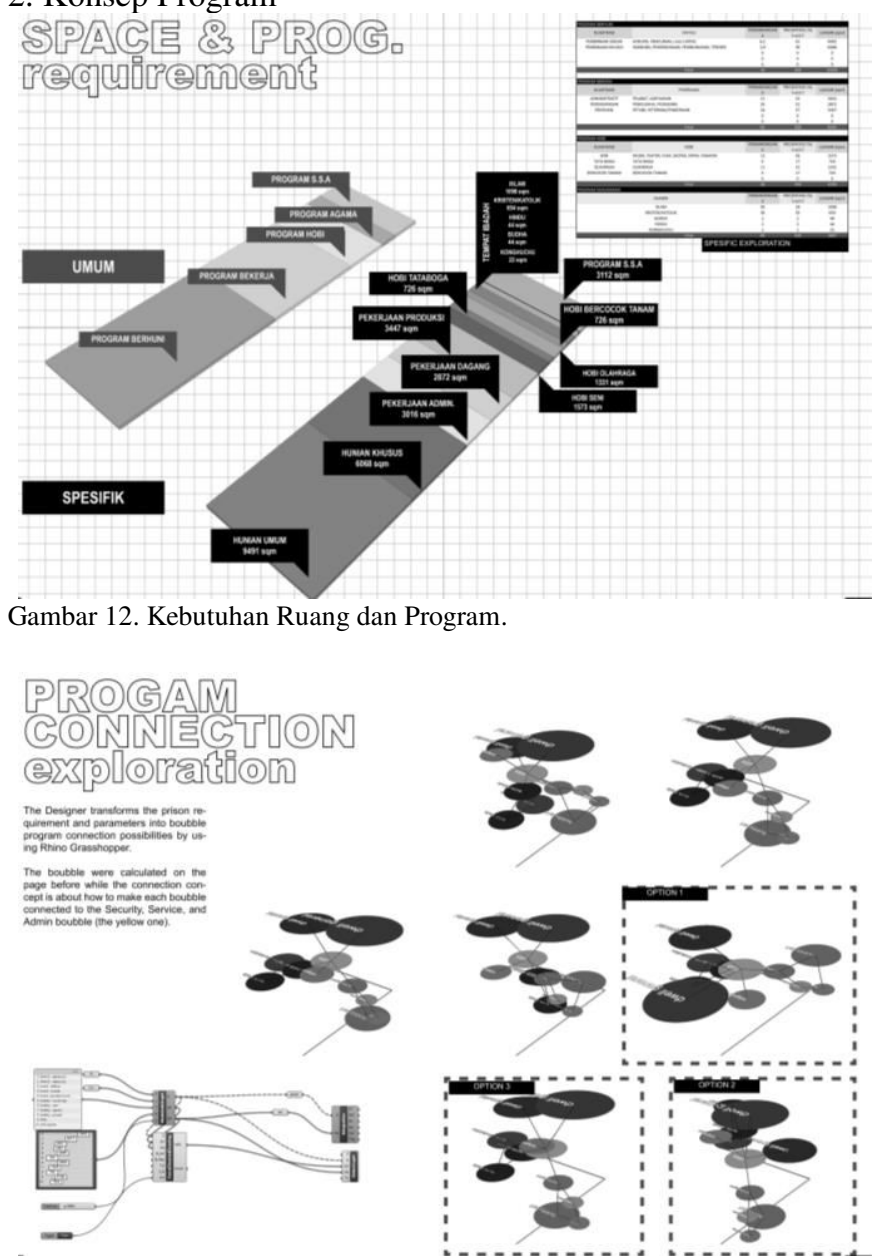

Gambar 13. Eksplorasi Program.
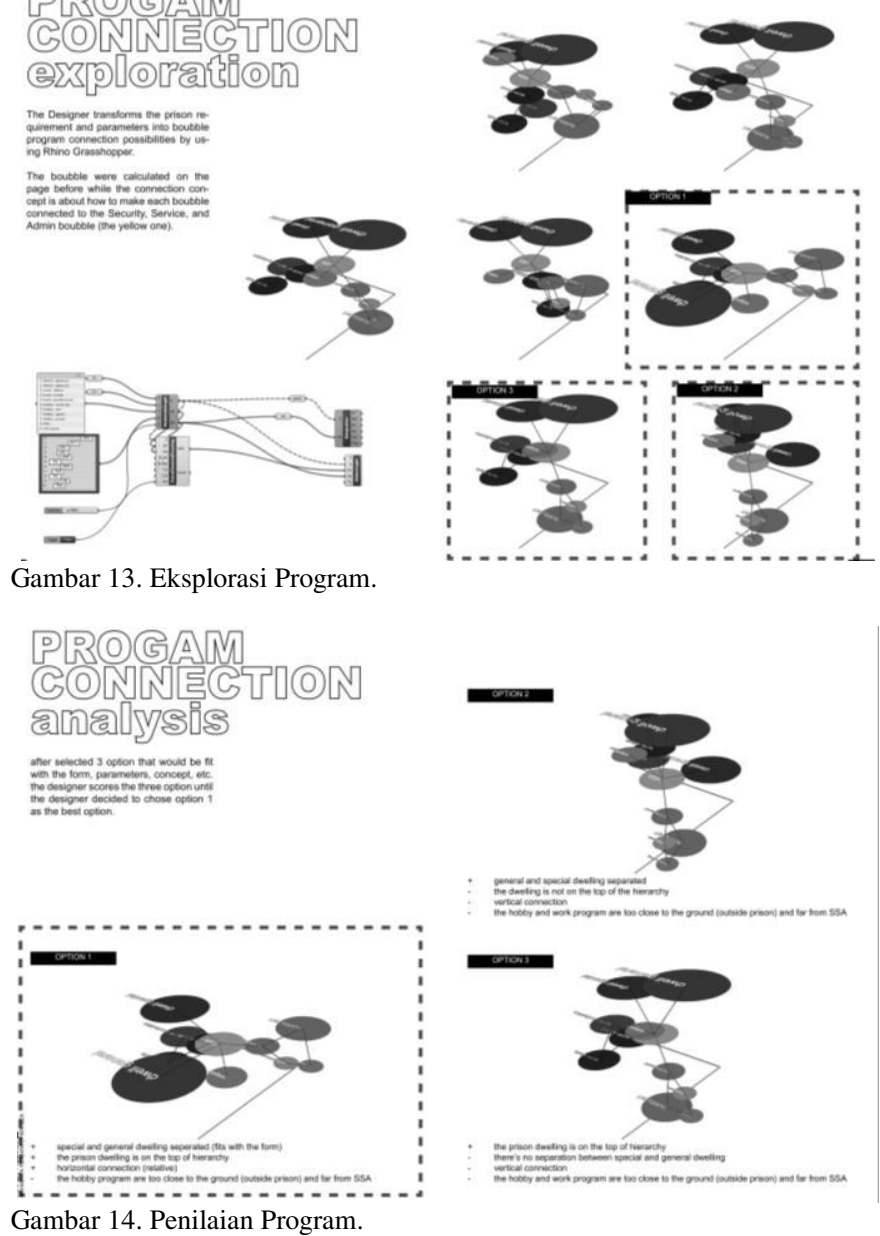

Perancang mencoba menggunakan bantuan perangkat lunak dalam menganalisa dan membuat posibilitas penataan program yang melibatkan parameter ukuran ruang, hubungan zonasi, dan hubungan skuens. Setelah menginput data perancang 
mendapatkan 7 kemungkinan yang kemudian perancang nilai secara kuantitatif hingga mendapatkan 1 komposisi program yang perancang anggap paling optimal.

\section{Konsep Skenario}

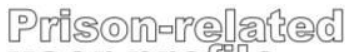

user? proffle
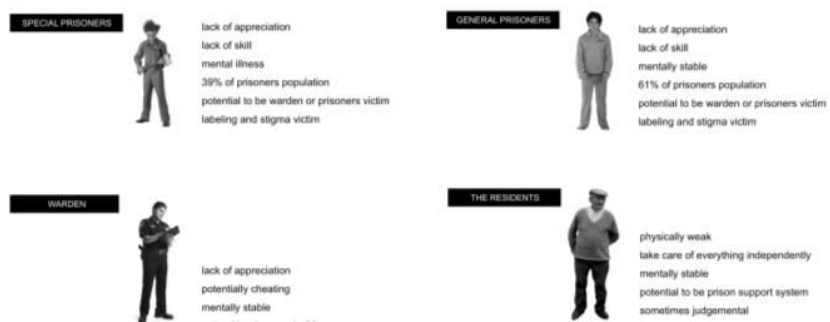

Gambar 15. User Profile

Untuk menguatkan situasi, suasana, dan cerita dalam rancangan penjara, perancang membuat beberapa opsi interaksi antar tiap pihak yang terlibat dan kemudian dinilai secara kualitatif hingga dipilihlah satu opsi yang paling optimal. Eksplorasi didasarkan konsep zonasi, konsep sekuens, konsep situasi, dan analisa pihak profil tiap pihak yang akan terlibat dalam penjara yang dibuat.

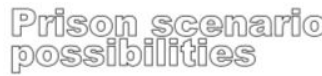
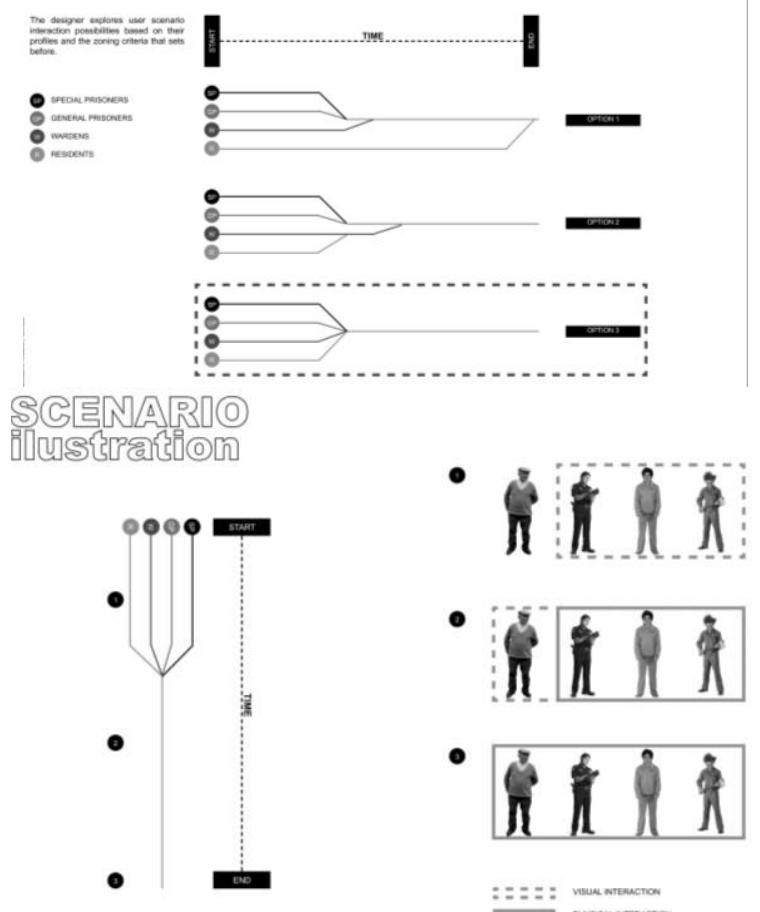

Gambar 16. Eksplorasi dan Penilaian Skenario.
Berdasarkan gambar diatas, scenario yang terpilih menunjukan akan terjadi interaksi tertentu pada titik tertentu diwaktu tertentu dengan skema pertemuan seperti gambar diatas.

\section{Layer Mix 2}

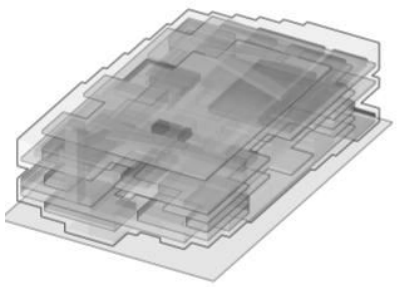

Gambar 17. Layer Mix 2

Berdasarkan 3 konsep spesifik yang telah diksplorasi dan ditentukan diatas, perancang menggabungkan kembali 3 konsep tersebut sebagai komposisi program bangunan penjara yang perancang anggap tepat untuk Rutan Klas I Surabaya.

\section{KESIMPULAN}

Pada perancangan ini objek penjara hanya merupakan tipologi atau objek uji dari isu yang perancang angkat yaitu tentang penggunaan metode pengolahan big data dalam perancangan sebuah arsitektur. Titik berat riset ini terletak pada proses perancangan arsitekturnya, tentang pengumpulan, pengolahan, dan pengambilan keputusan rancang berbasis data. Melihat hasil akhir rancang (dalam riset ini data mengantarkan perancang untuk menjadikan tipologi penjara sebagai objek rancang yang dianggap dapat mendapatkan dampak paling optimum dengan analisa big data) Penjara Medaeng Rutan Klas 1 Surabaya yang didasarkan oleh kompleksitas dan prefensi hidup manusia berhasil ditransformasikan menjadi aspek formal dari bangunan rancang dan hal membuktikan bahwa Big Data dapat juga diterapkan dalam mendesain sebuah perancangan arsitektur dan menjadi salah satu alternatif metode dalam merancang suatu arsitektur.

\section{DAFTAR PUSTAKA}

A. Gandomi and M. Haider, Beyond the hype: Big data concepts, methods, and analytics. Toronto: Elsevier Ltd, 2014.

[2] MVRDV, Metacity Datatown. Rotterdam: 010 publisher, 1999.

[3] W. Pena and S. A. Parshall, Problem Seeking: An Architectural Programming Primer. New York: John Wiley \& Sons Inc, 2001.

[4] S. Santoso, Statistika Parametrik. Jakarta: Elex Media Koputindo, 2010.

[5] Z. Soflin, "Data Driven Architecture." [Online]. Available: https://issuu.com/zachsoflin/docs/datadriven. [Accessed: 23-Sep2017]. 